\title{
The unkillable dream of the Great American Novel: Moby-Dick as test case
}

\section{Citation}

Buell, Lawrence. 2008. The unkillable dream of the Great American Novel: Moby-Dick as test case. American Literary History 20, no. 1-2: 132-155. doi:10.1093/alh/ajn005.

\section{Published Version}

10.1093/alh/ajn005

\section{Permanent link}

http://nrs.harvard.edu/urn-3:HUL.InstRepos:31740086

\section{Terms of Use}

This article was downloaded from Harvard University's DASH repository, and is made available under the terms and conditions applicable to Open Access Policy Articles, as set forth at http:// nrs.harvard.edu/urn-3:HUL.InstRepos:dash.current.terms-of-use\#OAP

\section{Share Your Story}

The Harvard community has made this article openly available.

Please share how this access benefits you. Submit a story.

Accessibility 
The Unkillable Dream of the Great American Novel: Moby-Dick as Test Case

@ 2007 Lawrence Buell

This essay is an interim report on a long-term study of the chimera of the great American novel-the dream either of writing it or seeing it written. The project has three main facets: a chronicle of the dispensations of authorial, critical, and readerly pronouncements (a story with a distinct beginning, several middles, and no end); historical-formalist comparative examination of several dozen aspirants and/or nominees; and a nation-and-narration metaperspective conceptualizing "American" narrative-in broadest terms-as part of a world system inflected by what Pascale Casanova calls the "Herder effect" (Casanova 78-81,), the postulate of each nation speaking in its own voice, within and against which its writers must thereafter contend, even such resolute cosmopolitans as James Joyce and Samuel Beckett.

This might seem a distinctly unfashionable project. First, as being out of phase with the push to think beyond/outside the confines of nationness for which Americanists, myself included, have lately been calling-as a counterweight to the overemphasis on US literary and cultural difference-the "literature of our own" phase, as it were-that long marked Americanist field-defining work. But beyond this: great American novelism as such would seem so quaintly paleolithic, long since dead a as a viable subject for literary history, criticism, theory. "Aside from pissing off the literati, does the Great American Novel, a monumentally $19^{\text {th }}$ century concept, serve any higher purpose?"-so starts one recent manifesto (A. Williams).

Indeed, the dream of the G.A.N.-initially reduced to acronym status by none other than Henry James1-has been killed off not once but at least twice. First, by degenerating into a media cliché soon after first launch-on the same level, one $19^{\text {th }}$ century critic dryly observed, as "the great American sewing-machine, the great American public school, [and] the great American 
sleeping car" (Allen 1403). It was killed off again with the rise of American literary studies as an academic specialization in the middle half of the $20^{\text {th }}$ century, by a string of articles dismissing the GAN as a naively amateurish age-of-realism pipe dream, "faded into the limbo of literary lost causes" (Knox 1968, 64).2 Scrolling more slowly through the decades, we find a bad-tempered equivalent of the "escalator effect" with which Raymond Williams metaphorizes the history of pastoral nostalgia: each generation fancying that the one before lived a life closer to nature (R. Williams 9-12)-but for Great American Novel commentary playing itself through as a discourse of repeated dis-enchantment: each generation seeing the one before as more gullible than itself.

Yet critical pissiness also suggests the persistence of some sort of hydrant, however phantasmal. Clearly neither critical skepticism nor authorial diffidence ever kept U. S. writers from attempting big national fictions, then or now. "Every American novelist," Maxine Hong Kingston once wrote, secretly "wants to write the Great American Novel”( Kingston 57-58). This during the runup to Tripmaster Monkey, one of the texts on my list.3 Or take the spate of Y-2K doorstop books summing up the century, or at least the half-century, such as Updike's The Beauty of the Lilies and DeLillo's Underworld. 9/11 may well generate the same. As my colleague Louis Menand remarked to me, no serious reviewer today would tout a book as the great American novel, yet it's hard to think of a major US novelist who hasn't given it a shot. The persistence in the face of skepticism and mockery of desire for a preeminent text (or select group of texts) that some day if not already might encapsulate national experience reflects some sort of entrenched quasi-understanding among authors, critics, publishing industry, and readers at large to read the national through $\mathrm{N}$ number of a perhaps infinitely extending series of putative master narratives-an alliance reinforced every time some random journalist compares Lyndon 
Johnson or George W. Bush to Captain Ahab stalking the whale-or when "Bush's brain," presidential advisor Karl Rove summed up the sense of being hounded by Democratic lawmakers as: "I'm Moby-Dick and they're after me" (Baker and Fletcher). Even that disaffected manifesto quoted earlier gets sucked into the vortex by going on to specify nine socalled "parameters" for GAN aspirants "that should go without saying," the last of which is that "It has to reference Moby-Dick as the Great American Novel" (A. Williams).

Regarding the obsolescence of the nation-focus, I hope to treat both narrative and critical centripetalism in the light of the messily hybrid and migratory character of the texts, tropes, and plot strategies under view-including the fascination with the animating big idea itself. Broadly speaking, the conception of "a" great national novel would seem to be one although hardly the inevitable outcome of "the national longing for form" (Brennan 44-70) in a context of postcolonial anxiety about cultural coherence and legitimation, such as obtained in the U. S. when the GAN first came into circulation. Why a counterpart discourse developed in some Latin American countries rather than others ( $c f$. Sommer), and why there is no equivalent in $19^{\text {th }}$ century German literary culture for Allesandro Mazzoni’s I Promessi Sposi (1842) despite the analogous condition of a populace culturally interknit striving to realize itself as a unified country may forever remain something of a mystery. For now, suffice it to say that U. S. literary-cultural history is not unique in its fascination with fictional narratives that promise to sum up the national essence nor by the same token need or should an inquiry into such lead to naive reaffirmation of U. S. literary autonomy.

Genesis, Premises, Templates, Dispensations

Often we can't specify when a concept gets put into circulation. Here, we can: a short essay of January 1868 by New England man of letters and Civil War veteran John. W. DeForest, 
author of a new novel that clearly tried to model his idea, Miss Ravenel's Conversion from Secession to Loyalty (1867)-one of those historically notable (Fluck 88-113) but subgalactic texts that keep getting rediscovered and then falling out of print.

DeForest envisaged a work that would capture "the American soul" through portrayal of "the ordinary emotions and manners of American existence" via a "tableau" that would grasp the full geographical and cultural range of national life, with the amplitude of a Thackeray, a Trollope, a Balzac (De Forest 27). To date, he argues, American fiction has been overwhelmingly "local" or sectional; moreover its best fiction writer, Hawthorne, captures "little but the subjective of humanity." The closest approximation is Harriet Beecher Stowe's Uncle Tom's Cabin (1852), which despite glaring defects did have "a national breadth to the picture, truthful outlining of character, natural speaking, ... drawn with a few strong and passionate strokes, not filled in thoroughly, but still a portrait" (28).

De Forest risked self-contradiction in taking for granted that there must be such a thing as an "American soul" when the literary evidence to date, by his own sayso, argued the opposite. He was myopic in positing that regional and national fiction must be antagonistic. So too his assessment of Uncle Tom's Cabin, which shows scant interest in slavery and racial division except as issues now happily resolved, much less in the possibility that a black novelist (say) might see things differently from a white one. Such limitations mark him as the product of a particular background and time: a white Anglo-American Yankee writing in the immediate aftermath of the War, with fictional realism coming into ascendancy, long before the critical establishment began to take serious notice of the large body of narrative writing by writers other than white protestants.

Myopic-yet prophetic too. Critical calls for an autonomous national literature dated back 
to the Revolution-but no substantive theory of what might actually constitute national fiction had congealed, due partly to the regional fissuring DeForest deplores. With the war behind and completion of territorial conquest and hinterland settlement in sight, so too (for the first time) was the GAN. It was, in short, arguably at once the leading literary edge of the "romance of reunion" between northern and southern whites (Silber, Blight)-and, beyond that, a leading literary edge of the broader push toward consolidation of the nation as literary, cultural, and political unit ( $c f$. Giles). Also pivotal was prose fiction's rising critical prestige stateside. Nina Baym, the most thorough student of antebellum fiction criticism, convincingly argues that the emergence of the GAN idea required a greater acceptance of prose fiction as a high art form than then obtained,4 however much Cooper, Sedgwick, Hawthorne, Poe, Melville, and Stowe, and others, helped make that emergence possible. Sure enough, I've unearthed only a few scattered antebellum references to "the great American novel," the earliest an advertisement for a 1852 London penny edition reprint of-fortuitously-Uncle Tom's Cabin, a promotional hype that simply touts its runaway best-seller status.5

De Forest's essay was also prophetic in its concurrence with a rising tide of nation-centric theory abroad. The conception of national literature as national expression in Hippolyte Taine's just-published Histoire de la litérature anglaise (1863) would have immense influence on latecentury formulations of American literary/cultural difference (Evans 12-13, 92-93). This too was the eve of Ernest Renan's seminal essay, "What Is a Nation?” (1882), which defined "a nation" as "a soul, a spiritual principle," entailing "the possession in common of a rich legacy of memories" and "the will to perpetuate the value of the heritage that one has received in an undivided form" (Renan 19). That personification is the remote origin of the most influential treatise on nationalism in recent times, Benedict Anderson's Imagined Communities (Anderson 
15 and ff passim), which reinvents nationalist theology as mythic fabrication.

Anderson of course theorized the nation as the fruit of collective imagination, not primordially "there." Whatever its shortcomings ( $c f$. Bhabha), this model without question intensified literary-critical attention to the historic role of literature and the arts in the work of nation-building. Through an Andersonian prism, nations seemed indeed to "depend for their existence on an apparatus of cultural fictions in which imaginative literature generally plays a decisive role"-in the first instance the novel particularly (Brennan 49). De Forest himself would never have made such big claims about the American novel, which for him barely existed. His standpoint was far closer to Renan's: that national fiction presupposed a national soul, not that fiction was a nation-building force. He shows no interest for example in Uncle Tom's Cabin's activist thrust, much less its possible role in touching off the Civil War. Yet he took the notion of nation-building and fiction-building as intertwined projects to a new plane of assertion that haunted later novelistic and critical practice. The very naivete of Taine's, Renan's, and De Forest's hypostasizations relative to Anderson's demystification of nation as a produced effect abetted the mentality that a nation's artifacts might embody nationness even if not create it.

At all events, GAN soon entrenched itself a term of reference for publishers, reviewers, and critics, despite the skepticism it provoked.6 Though used more as epithet than as a concept defined with any precision, several specific connotations quickly took hold.

First, GAN discourse commingles retrospect with anticipation, typically stipulating that the great work remains unwritten, although some previous named effort points the way. When a specific claim is lodged, except for publisher advertisements of new titles it's usually a novel a decade to a generation or more older. Second, GAN discourse therefore correlates broadly-but unevenly-with evolving canon theory, increasingly appropriated-though never monopolized-by 
the professoriat. On the one hand, GAN talk is a far more open, participatory, discourse, as evidenced for example during the early years by contributors' columns in newspapers and magazines and in our own time by internet blogs. Googling "great american novel” while drafting this essay yielded 27,500,000 hits, (many of them redundant, of course). On the other hand, both late Victorian common readers and turn-of-the-21st-century bloggers have regularly been swayed, even against their intuitive judgments, by what they take to be critical consensusas for instance with those today who accept Moby-Dick as a possible GAN while confessing that they don't much like or understand it.7

A third constituent is the paradox of the one and the many. Although the mythical GAN is regularly hypostasized as a singular, unique "the," more often than not it's taken de facto as a plural category. One can readily think of it as, say, a top five, as with the much-publicized 2006 New York Times poll of the best American novels of the past quarter century. (Toni Morrison's Beloved received the most votes overall) (Scott 16-19). Or as an open, even infinitely extendable series. This pluralization comports with the disputes over criteria dating back to De Forest. Should regional fiction be disallowed? Frank Norris, for one, claimed the opposite (Norris). Should the setting necessarily be American? Edith Wharton argued the contrary (Wharton). Must it be a realist mimesis? Most authors and readers seem to have thought so, especially through the 1930s, but many objected from the start, anticipating the now-discredited but hardly defunct correlation first suggested by D. H. Lawrence and F. R. Leavis of romance as the mark of American fictional difference8-a claim also sometimes made (on rather different grounds) for Latin American narrative as well (e.g. Glissant 105).

So even though the GAN has typically been deployed as a labeling device, it implies also a rudimentary conceptual matrix, an incipient critical problematics-and not merely for the score 
of novels most commonly so named by those who play the game, but also as a basis for mapping the whole, massively complex ever-changing flow of narrative discourse in U. S. history since its inception.

Several recipes or formulae-not mutually exclusive-seem to facilitate, though hardly ensure, GAN status. The most obvious and sure-fire is to have been subjected repeatedly to a series of memorable rewritings (in whatever genre or media), thereby giving the text a kind of master-narrative status whether or not it aspired to such. Of this The Scarlet Letter-the most durably canonical classic American fiction-is my favorite premodern demonstration case, both despite and because it is arguably at least as much a diasporic or "Atlantic world" narrative as an “American" one, despite having traditionally been treated by Americanists as a designedly fictive myth of national/Puritan origins ( $c f$. Buell 2005). Recipe two might be called the romance of the divide (or “divides," plural), fictions of sectional and/or ethno-racial division instantiating that division in the form of a family history and/or heterosexual love affair, which thereby becomes a national synecdoche. De Forest's Miss Ravenel builds around this trope, though by far the most influential early text is Uncle Tom's Cabin. Recipe three is a narrative centering on the lifeline of a socially paradigmatic figure, (traditionally male, but diminishingly so) whose odyssey tilts on the one side toward picaresque and on the other toward a saga of personal transformation-or failure of such. Among premodern candidates, Huckleberry Finnstands out in later critical accounts if not in its own time. An expanded variant of the socially representative protagonist mode, indeed arguably a category of its own, is the paradigmatic family saga, as in Gertrude Stein's The Making of Americans, William Faulkner's Absalom, Absalom, and John Steinbeck's Grapes of Wrath. Still another recipe is the heterogeneous symbolic assemblage of individuals, often positioned in a confined space in the 
service of a common task or defined against the background of an epochal public event, constituting thereby an image of "democratic" promise and/or dysfunction. Here Moby-Dick, with its complex ideologization of the shipboard microcosm, the global village that is the Pequod's crew, today stands preminent among "classic" U. S. fictions. That Scarlet Letter, Uncle Tom's Cabin, Huckleberry Finn, and Moby-Dick have in fact been cited in latter-day lists of possible GANs more often than any other premodern texts 9 of course confirms the ongoing influence of critical canonization (in Stowe's case, recanonization), ratified by school syllabi and artistic recyclings at various levels of sophistication from pop to avant-garde, in shaping public memory of what counts as monumental in the distant past if not the near distance.

These encapsulations, formulistic though they are, should substantiate why a Great American Novel project must be transnational-and transgeneric as well. Recipe number three, for example, can't be understood without taking into account antecedent picaresque and Bildungsroman traditions, not to mention such nonfictional prototypes as slave narrative, conversion narrative, and Franklinesque success stories-none of whose provenances are distinctively national. The same holds for novels like Moby-Dick that build on the heteroglot assemblage scenario: e.g. Frank Norris's The Octopus (especially if considered as the first of an unfinished trilogy), Dos Passos' U.S.A. trilogy, Mailer's The Naked and the Dead (steeped in both Melville and Dos Passos), and Pynchon's Gravity's Rainbow (steeped in Melville if not also Dos Passos).

Perilous though schemes of periodization always are, for rough and ready purposes one might distinguish three phases of GAN discourse. During the late 1800s, the basic templates and defining issues were set in place. Then came a further surge of interest among writers and reviewers, followed by expressions of disavowal by the emerging literary-scholarly 
establishment. On the one hand, a number of major novelists increasingly weighed in during the first third of the $20^{\text {th }}$ century with position statements bespeaking personal investments in the GAN (e.g. Norris, Wharton, Lewis per Schorer 302, Dreiser), and the most exhaustive attempts yet to actualize the GAN-whether or not directly so professed-hit the market: e.g. Dreiser's $A n$ American Tragedy (1925), Stein's The Making of Americans (published 1925, though written 1911), and Dos Passos' U.S.A. trilogy (1930-7). It's tempting to see the 1920s (also the decade of the slow-selling but now perennial nominee Great Gatsby and faded contender Babbitt) as a breakthrough point, somehow also connected with the rise of the U. S. to acknowledged world power status and the birth of American literature as an academic discipline. Yet however influential these developments in promoting circulation and prestige of U. S. worldwide the professionalization of American literature studies also reinforced a dismissive view of the GAN idea as amateurish sloganeering on behalf of a dubiously middlebrow project not to be confused with what really counted in modern fiction, the high modernist revolution from James and Conrad on10-a judgment explicitly seconded by (some) creative writers. New journalist Tom Wolfe, for instance, drew on Lionel Trilling's critique of Dreiseresque social realism in explaining “Why They Aren’t Writing the Great American Novel Anymore.” Answer: the panoramic social novel was dead: "Most serious American novelists would rather cut their wrists than be known as 'the secretary of American society"'-Balzac's self-description. "With fable, myth and the sacred office to think about-who wants such a menial role?" (Wolfe 157).

Since Wolfe wrote this (1972), indeed since World War II, precious few novelists or critics of stature have deigned to treat the GAN as a credible idea or enabling myth. British writer Martin Amis' defense of Saul Bellow's Adventures of Augie March as the book that "retired the cup" (Amis 114) and American novelist Jane Smiley's of Uncle Tom's Cabin as the 
book that should have been the ur-text for American fiction rather than Huckleberry Finn (Smiley) are conspicuous exceptions. More indicative of the distinct unfashionableness of GANtalk is Norman Mailer's gun-shy tribute to Dos Passos: “'If we have any one great American novel, and perhaps we don't, but if we do; it would be U. S.A."” (Mailer). Still, notwithstanding its ostensible second death, the idea lives on as mantra and as aspiration-and this because as well as despite the double-whammy of the modernist (and postmodernist) revolutions and the critical sophistication of U. S. literature studies with the academicization of the field.

How can that be? Well, for one thing the desire to produce and consume social realist fiction has never gone out of fashion, and furthermore it's tended to renew itself by hybridizing with modernist and then postmodernist experimentalism. Among latter-day contenders and/or nominees, witness Augie March, behind which stands Dreiser as well as Whitman and Twain; Invisible Man, behind which stands Dostoyevsky as well as Emerson, Twain, Faulkner, and African-American musical and oral vernacularity; and De Lillo's Underworld, a hybrid of oldfashioned chronicle fiction and postmodern tonal flatness, ludic parody, and scrambled temporality.

Second, the dream of the GAN has arguably gained more than it's lost as the result of the related phenomena of multiple ethno-literary renaissances starting in the 1920s and the two-stage process within American literature studies of first winnowing the U. S. literary canon down to a select number of galactic luminaries during the middle third of the century, followed by the contestation of the distinctly white, male, protestant, politically liberal result on behalf of (especially) women and nonwhite writers this process marginalized. The winnowing phase helped catalyze inter alia the Melville revival, Faulkner's canonization, and what Jonathan Arac shrewdly calls Huckleberry Finn's "hypercanonization"-a term that might also be applied to 
(say) Moby-Dick and Great Gatsby, also beneficiaries of this mid-century winnowing process now seemingly become permanent classics, pedagogical staples, and fixtures on popular lists of top-GAN possibles. The (re)opening of the canon in the 1970s and after inter alia reestablished Uncle Tom's Cabin as a towering-however dubious-presence in U. S. fiction history and helped prepare the way for Morrison's Beloved (central to which is the historical incident Stowe drew upon for Eliza Harris' escape and Cassy's infanticide) to top the 2006 New York Times poll. But what especially deserves stressing here is the complex symbiosis between the canonical winnowing phase and the revisionist phase that displaced it. For example, the mid-century critical apotheosis of Huck Finn that Arac skeptically demystifies, from humorous bad-boy picaresque suspiciously tolerant of white hegemonics to elevating conversion narrative of southern lad resolved to go to hell rather than return friend Jim to slavery (Arac 37-182), strengthened its eligibility as a pre-text for both Bellow's Augie and Ellison's Invisible Manbreakthrough achievements in Jewish and African American fiction that updated the recipe of the socially representative protagonist by fusing "mainstream" precedent with "ethnic" narrative traditions emanating from Jewish immigration narrative and slave narrative respectively. Reciprocally, the interlinked critical rehabilitation of slave narrative and the rise of contemporary neo-slave narrative (Rushdy)-both minoritarian variants of the socially representative protagonist-centered recipe-helped create the feedback loop that generated rereadings of Huck Finn itself as strongly inflected by slave narrative (e.g. Andrews, Mackethan, Mensh and Mensh 34-45 and passim).

Third, the GAN idea continues to thrive among the extracademic reading public. Though it may have died out as a topic for "serious" scholars, short-take website manifestos, chatrooms, free-lance postings of lists of GAN contenders abound and multiply freely. To characterize this 
as a bottoms-up verdict of the "common reader" against the critical establishment overstates the case, given that internet access correlates with economic status, GAN commentators comprise but a small fraction of all readers, and their verdicts don't diverge hugely from standard college syllabi. What's out there might better be called a quasi-recycling, quasi-cutting loose of (ex)pupils from schoolroom tutelage. From a magisterial standpoint, it's tempting to discount this barrage of cyber-miscellanea as a symptom of the naive hankering to which books like E. D. Hirsch's Cultural Literacy, Alan Bloom's The Closing of the American Mind, and Harold Bloom's The Western Canon cater: the desire for authoritative standards of literary judgment. But that too is simplistic. For one thing, blogosphere discourse regularly intermixes serious with jocose, generally quite aware (as GAN discourse has always been) that the term belongs in quotation marks even as one joins the game with gusto. Why then participate to start with other than just to sound off? Most obviously and fundamentally, to affirm a memorable reading experience. Beyond this, one finds an intriguingly question-begging desire to address what sort of image of Americanness might be encoded therein. Often this move seems less driven by any investment in the national as such then by the presumption (How responsible are we professors/critics/reviewers for implanting it?) that this is what American texts $d o$, or at least this is the way one is talks about them. Even more striking about such comments, is how seldom they posit or contend, that a GAN must be celebratory or nationalistic. Contra the thrust of academic Americanist criticism since new historicism to pin down canonical texts' ideological valences and especially the senses in which they might abet dominant political formations, freelance GAN punditry seems at least as interested in how the novels in question disrupt mainstream pieties. Which is after all what one might typically expect a person to say about a life-impacting book. 
This lively conversation raises the provocative question of how an old-fashioned yearning for monuments stubbornly persisting into today's putatively postcanonical era can manage to coexist with a strong penchant for images or performances of national failure and with a fuzzy, inchoate sense of the "national" itself. I hope to explain the logic(s) of that paradox by reanalysis of several dozen fictive exempla in terms of the generic "masterplot" structures and intellectual genealogies that inform and reticulate them, in the context of the long history of GAN discourse telegraphically sketched here.

A look at the case of Moby-Dick, than which no U. S. novel has been more monumentalized since 1950, not even Huck Finn, may help concretize some of this. To make discussion manageable, I focus initially on the genealogy and implications of a single favorite Melville motif.

\section{Moby-Dick and the Specter of Anacharsis Cloots}

The image in question is the spectacle of the thirty-some delegation led by Prussian baron Jean-Baptiste (aka "Anacharsis") Cloots (1759-94), self-styled "orator of the human race," before the French Assembly in 1790, purporting to represent "the 'oppressed nations of the universe" in their national costumes, congratulating it for having "restored primitive equality among men"" and promising that 'encouraged by the glorious example of the French, all the peoples of the universe ... would soon break the yoke of the tyrants who oppress them'" (Schama, 474; Labbe, 305). Here are the three passages.

They were nearly all Islanders in the Pequod. Isolatoes too, I call such, not acknowledging the common continent of men, but each Isolato living on a separate continent of his own. Yet now, federated along one keel, what a set these Isolatoes were! An Anacharsis Clootz deputation from all the isles of the sea, and all the ends of the earth, accompanying Old Ahab in the Pequod, to lay the world's grievances before that bar from which not very many of them came back. (Melville 1852, 121) 
As among Chaucer's Canterbury pilgrims, or those oriental ones crossing the Red Sea towards Mecca in the festival month, there was no lack of variety. Natives of all sorts, and foreigners; men of business and men of pleasure; parlor men and backwoodsmen ... Northern speculators and Eastern philosophers; English, Irish, German, Scotch, Danes, Santa Fé traders in striped blankets, and Broadway bucks in cravats of cloth of gold; fine-looking Kentucky boatmen, and Japanese-looking Mississippi cotton-planters; Quakers in full drab, and United States soldiers in full regimentals; slaves, black, mulatto, quadroon; modish young Spanish Creoles, and old-fashioned French Jews; Mormons and Papists; Dives and Lazarus; jesters and mourners, teetotalers and convivialists; deacons and blacklegs; hard-shell Baptists and clay-eaters; grinning negroes, and Sioux chiefs solemn as highpriests. In short, a piebald parliament, an Anacharsis Cloots congress of all kinds of that multiform pilgrim species, man. (Melville 1857, 9)

In jovial sallies right and left, his white teeth flashing into view, he [the handsome black sailor the narrator remembers having once seen in Liverpool] rollicked along, the center of a company of his shipmates. These were made up of such an assortment of tribes and complexions as would have well fitted them to be marched up by Anacharsis Cloots before the bar of the first French Assembly as Representatives of the Human Race. At each spontaneous tribute rendered by the wayfarers to this black pagod of a fellow-the tribute of a pause and stare, and less frequently an exclamation-the motley retinue showed that they took that sort of pride in the evoker of it which the Assyrian priests doubtless showed for their grand sculptured Bull when the faithful prostrated themselves. (Melville 1924, 2469)

Melville doubtless got this cameo from Carlyle's History of the French Revolution, which scoffingly treats the incident as a sideshow perpetrated by a loony utopian and hypocrite to boot, a bon vivant patrician masquerading as a man of the people (Carlyle 269-270). So too Simon Schama in the leading narrative history of our time, lumping Clootz with the "lunatics and thugs on the left" (Schama 808). But Melville's first and third iterations if not also the second find something poignantly riveting about the raggle-taggle melange of human types. He evidently grasped that Cloots was both an unstable overreacher destined to join the ringleaders of the Terror only to be purged as an extremist by Robespierre just before his fall, yet 
also a committed advocate of the first-ever statutory declaration of Human Rights--the 1789 Declaration of the Rights of Man and Citizen (Hunt 16, 220-223), distinctive among his fellow revolutionaries for extension of equal rights to all peoples of the world. From his brother Gansevoort's political travails as well as from Carlyle, Melville would have recognized "Anarcharsis Cloots" as a conservative byword for political demagoguery (Rogin 61), and from Thomas Paine's Age of Reason he would have perceived the sense of fraternity between Clootz and that most wayward of the nation's founders (Paine 731): as a fellow anti-clerical, as the only other non-French member of the Revolutionary Convention, and as a conscious disseminator of the idea of human rights transnationally.

To view Melville's fictive social microcosms through this Clootsian lens is to foreground the elasticity of his investment in the national as such. The Confidence-Man's passenger list embeds what at first looks like its distinctively national collage within a universalized framing conception of all humanity on pilgrimage. -As if frontier America were just one site of a much more far-reaching ritual process, or agenda of social possibility. Its bemusement sits at the opposite end of a continuum from the open-eyed wonder of Malcolm X beholding the unimaginable multiracial concourse of the Hajj. The handsome black sailor vignette has far more to do with comradeship than nationness, functioning as one of a series of heterotopic diversions from or postponements of the mainplot's cooptation by the blinkered state of emergency Captain Vere imposes on the Bellipotent under claim of national security, starting with Billy's successes aboard the significantly-named Rights of Man. The Moby-Dick passage conceives the Pequod's federation of isolatoes at least as much as a funky League of Nations as of capitalism Yankee style headed for destruction, though it's that too. It too underscores how Melville's fictive 
microcosms and indeed the whole set I take up from the Templeton of James Fenimore Cooper's Pioneers (1823) (cf. Simpson 155-183) to Karen Tei Yamashita's Tropic of Orange (1999) is in the first instance an age-of-revolution legacy that extends itself in multiple directions and spatial scales, other than just the national, key to Moby-Dick's plot though it also is that the coffin the Pequod turns into could only have been made in the States.

Still more elastic, and commensurately more problematic, than the symbolic geography of Melville's refigurations of Cloots is their informing vision of social solidarity and order. To get at that, I turn to C. L. R. James, the first commentator to identify Moby-Dick's globalhistoric import as a prophetic rendition of the consequences of U. S. transnational capitalism dramatized by its meticulous portraits of the crew, its work-world, and the supremely competent captain driven mad by the system within which he has risen-who for James uncannily anticipates "how the society of free individualism would give birth to totalitarianism and be unable to defend itself against it" (James 2001, 12-15, 50, 54). Also one of the few Melvillians to take seriously his fascination for Cloots, James also strenuously distances the two. "Whereas Clootz thought of uniting all men in a Universal Republic, based on liberty, equality, fraternity, brotherhood, human rights, etc., Melville ... had not the faintest trace of these windy abstractions .... His candidates for the Universal Republic are bound together" by their world of work" (James 2001, 19-20). This comports with James's most daring claim, that Melville "intend[ed] to make the crew the real heroes of his book, but [was] afraid of criticism." From which it follows that the nutty fantast Cloots must be rigorously distinguished from the "meanest mariners, renegades and castaways," who "remain sane and human" (James 2001, 18, 48). 
Here, however, James's horizon arguably gets foreshortened by what Donald Pease calls the "future anterior" mode of his act of reading (Pease 2004, 216), the context of vainly desiring a contemporary mutiny, consigned as he was with fellow detainees to Ellis Island by Cold War xenophobia on the way to deportation. James's desire to immunize Melville against Cloots bespeaks an inconsistency in his reading of Ahab both in relation to Ishmael (whom James dismisses as the wrong kind of isolato, the impotent intellectual: "the man without will") (James 1993, 84), by contrast to whom Ahab is the robustly forceful veteran seafarer gone wrong, and to the crew, by contrast to whom he's a mad despot. James's odd mixture of respect and disdain toward Ahab resonates with Melville's several enlistments of the Cloots pageant to hint at key issues of social control: how, whether, and to what end a heterogeneous crowd is to be made coherent, in the service of whatever collective purpose. The Confidence-Man imagines a leaderless assemblage cohering only around a vague conception of pilgrimage, remaining little more than a bemusing metonymic series of antithetical etceteras. Billy Budd imagines a natural aristocracy harmonized from the top down by the handsome sailor's charisma. The Moby-Dick version, most complexly, imagines an otherwise unassimilable group of men marshaled into ad hoc order by a leader purporting to rectify the world's grievances. The pivotal verbs "federated" and "accompanying" both equivocate as to the compulsion vs. voluntarism required, and the metaphor of petition also equivocates as to the nature and validity of the "grievances." Comprehensive inclusiveness and purposeful orderliness, even hierarchical in some sense, seem proffered as terms both of worth and danger.

Such hedging is not merely local to the Clootz motif. Throughout, it drives Moby-Dick's 
equivocal macro-structure as an observer-hero narrative ( $c f$. Buell 1979), its dual epicenters of Ahab, the purposeful man who compromises his agenda as little as he can, vs. Ishmael, the man of reflection who problematizes that agenda to the maximum: the mentally hyperactive, sometimes hilariously irreverent critic of Ahabian dominance also enmeshed by it in voice as well as body, suffusing his meditations to the point that magnifies, indeed mythifies, the stakes of the quest even as he "resists" it through his combination of critique and parody. But unlike other observer-hero narratives-Heart of Darkness, Great Gatsby, Thomas Mann's Doctor Faustus, et al.-Moby-Dick's first personness notoriously disappears for the last part of the text save the epilogue-a swerve often deemed a flaw but arguably a stroke of genius, dramatizing a further stage of usurpation of the novel's primary counter-voice during the last stages of the chase, though without authorizing the usurping hero, since the narrative voice now becomes the olympian third-person that orchestrates all of Melville's subsequent long fictions. Here MobyDick as rhetorical construct renegotiates for the last time the question posed repeatedly from "Extracts" on, quintessentialized by the Cloots vignettes-the conundrum at the heart of democratic philosophy: the extent to which and the authority by which an assemblage shall be subject to order vs. collectively or individually empowered.

The correspondence between this muting of the dramatized narrator and Moby-Dick citations at the level of popular culture during the past half century is striking. One of the conspicuous ironies of this novel's canon history is that since it achieved great American novel status and through whatever process of cultural-capital-incentivized trickledown it become a text of frequent reference for journalists, cartoonists, and bloggers as well as for academics, ther's 
been a pronounced disconnect between the predominant critical identification with the Ishmaelean perspective ushered in by Matthiessen's American Renaissance (Mathiessen 396466) and later subjected to ideological critique by revisionist Americanists as symptomatic of Cold War era free-world liberal anti-Stalinism and the popular reception of Moby-Dick during the same period (and beyond).11 In the popular discourse, Ishmael scarcely exists, unless one counts novelistic echoes (e.g. Kurt Vonnegut's "Call me Jonah" to open Cat's Cradle or Thomas Pynchon's Tyrone Slothrop in Gravity's Rainbow). 1950s filmgoers remembered not the Ishmael of Richard Baseheart but the Ahab of Gregory Peck (an American literature concentrator as a Berkeley undergraduate). Modern Moby-Dick cartoons are nearly all about Ahab and the whale, like my own personal favorite, a Rene Baur creation that drolly alludes to Clootsian prosecutorialism through an imagined courtroom scene where Ahab is in the dock being crossexamined by an attorney, harpoon in hand, on behalf of the white whale, who sulks in the background: "So, Captain Ahab, I put it to you that you were deliberately stalking my client.12 Another striking feature of media recyclings of Moby-Dick is their variegated political valence. They aren't the monopoly of the left or the right; nor do they always put a "totalitarian" or even negative spin on Ahabian presumption. As a negative image of vengeful monomania, Ahab may stand not only for the American military-industrial establishment's obsession with Vietnam or communist China, or Reagan's with the Sandinistas in Nicaragua, or Kenneth Starr's prosecution of Clinton, but also for the liberal media's alleged conspiracy against Nixon, for Nixon's fraught relation to Eisenhower ("awe and fascination soured with fear and a desire to supplant"), for anti-corporate harassment of Microsoft's monopolism, for Rudolph Giuliani's 
prosecution of Drexel Burnham Lambert as District Attorney of New York City, for Canadian fishery officials' voting for selective lifting of the international ban on whaling, etc. - In the course of which Ahabism sometimes also gets softened into a synonym for quixoticism of whatever sort, like Adlai Stevenson III trying to form a third party in Illinois to stand against Governor Jim ("The Whale") Thompson, British Prime Minister John Major trying to control a "whale of a depresssion," or New York Yankee slugger Roger Maris, the first to break Babe Ruth's home run record in 1961, not quite managing to do it in the span of the old-time 154game season. Which can mean, a quite sympathetic view of Ahabas with the baseball story (by prominent African American columnist James Reston, for whom Ahab seems one of the great legendary "gallant failures of life."13

Repoliticize that diagnosis at a more intellectualized level, and one gets the neoLawrance Thompsonian version of Ahabian "madness" that launched contemporary Americanist whiteness studies, Toni Morrison's “Unspeakable Things Unspoken” (1988) which rehabilitates Ahab as the indispensable agent of resisting hegemonic whiteness: "the only white male American heroic enough to slay the monster that was devouring the world as he knew it" (Morrison 143, Thompson).14 Even though Morrison makes a special point of stressing the importance of the "Whiteness of the Whale" chapter, like the journalistic fraternity at large she deletes Ishmael: the challenge to the baleful racist status quo is entirely Ahab's. Here we see a fortuitous rounding back to what seems to have been the very first African American commentary on Moby-Dick, that of antebellum African American physician and polymath James McCune Smith, in Frederick Douglass' Paper (1856),for whom the lesson of the novel as a 
meditation on the possible righting of social wrongs boiled down to the necessity of firm rather than feckless anti-slavery leadership (McCune Smith 146).

None of this proves that Moby-Dick itself validates Ahabian force against Ishmael's dubieties or the claims of cross-cultural sociality, nor that popular culture is wiser than academic criticism. But no less self-evidently, extra-academic, middlebrow, and even lowbrowhipshooting retakes of supposed masterplots (what Pierre Bourdieu calls "naive citatology" [Bourdieu 139]) must be factored into any serious analysis of what counts as great American novelism in order to be faithful to the legacy of this (or any culturally influential) narrative, all the more so given than the GAN idea itself is and has always been more a demotic than an academic enthusiasm. Books that accrue GAN charisma inevitably get appropriated in multiple disparate ways, uncontrollable beyond a point by the original authorizing "institutions which conserve the capital of symbolic goods" (Bourdieu 121), in this case critical and pedagogical establishments. Moby-Dick is notable but not unique in provoking such mutiny, readerly hijackings orthogonal, even antithetical, to "established" interpretations. Individually, they're often laughable; collectively they're worth noting; sometimes (e.g. McCune Smith, Morrison) they're deeply interesting. In the present case, as I've tried to show, one if not the only revelation to be gleaned from the unofficial discourse generated by Moby-Dick since it achieved GAN status is its reminder that the novel's central figure of resistance against whatever limit condition (whether or not deemed legitimate) is Ahab, not James's mariners, nor the Ishmael of Cold War liberal critics who followed Matthiessen's lead, nor the recuperated Ishmael of critics of Cold War critical revisionism (cf. Spanos). All this follows logically from Moby-Dick's 
version of the Clootsian microcosm: Cloots the impressario of that otherwise anonymous delegation of heteroglot delegation of multinationals. That encapsulation predicts Moby-Dick's revisionist swerve from the standard observer-hero plotline, a performance that in turn helps ensure that when boiled down ex post facto to the bare bones, according to what would seem to be a general rule of popularization of classic texts (Cf. Preston 32-33, on Robinson Crusoe and Gulliver's Travels), it gets effectively reduced to the faceoff between Ahab and the whale.

Meanwhile, the metamorphic reinvention of the Cloots vignette in Melville's later work bears out the experimental cast of his own thinking, registered obliquely by the element of drollery in latter-day popular appropriations, considerably more common than what one finds in reception history of (say) The Scarlet Letter. Melville invests Cloots (and much else in MobyDick besides) with a Carlylean grotesquerie that leaves it to the reader to surmise at every point whether what's being ventured is prophecy or parody or both. The effect presages the reprise of Marx-Engels passionate-sardonic invocation of Europe haunted by the communist "specter" reprised in Derrida's metahistorical Specters of Marx, where the infusion of the ludic into the passionate also reflects-among other motives-self-conscious ambiguation of seemingly failed enterprise(s), Clootz's and the Pequod's in the one case, the "collapse" of Marxism in the other (Derrida). Moby-Dick stands somewhere in between taking the prospect of some future completion of democratic-style heroism seriously and spoofing it as doomed from the get-go owing to whatever combination of leaderly hubris and fecklessness on the crew's part. This problematic is more or less shared by the other novels I've mentioned that employ the heteroglot assemblage device, the GAN template of which the Cloots cameo in miniform and the whole 
dramatization of the shipboard microcosm it miniaturizes are avatars. Here and elsewhere, the admixture of hopeful and sardonic tonalities inherent in Moby-Dick's treatment of the Clootsian pageant of liberty's needful extension throughout the world resonates with Eric Foner's glasshalf-empty, ironic but hopeful scenario of freedom in U. S. history as a history of not-yetrealization (Foner).

All this to my mind argues for the unkillability of the GAN aspiration itself, indeed for the likelihood of its thriving all the more vigorously under threat of national emergency or decomposition, insofar as a hankering for the GAN-whether conceived as singular or pluralbespeaks a continuing desire for vicarious participation, however skeptical, in a work of social envisionment conceived as still and maybe forever incomplete. Whether after another 150 years this process will seem to have worked more toward the end of realizing robuster images of democratic inclusion than toward reinscribing an ideology of natural aristocracy, social darwinism, or the cynicism of ideals repeatedly betrayed, remains an question. But this very openness will help ensure that the GAN lives on as fantasy if not as achieved result.15 


\section{Bibliography}

Allen, James L. “The Great American Novel,” Independent (July 24, 1891): 1403-04.

Amis, Martin. “A Chicago of a Novel,” Atlantic Monthly, 276 (October 1995): 114-127.

Anderson, Benedict. Imagined Communities: Reflections on the Origin and Spread of Nationalism. London: Verso, 1983.

Andrews, William L. “Mark Twain and James W. C. Pennington: Huckleberry Finn’s Smallpox Lie," Studies in American Fiction, 9 (Spring 1981): 103-112.

Anesko, Michael, ed. Letters, Fictions, Lives: Henry James and William Dean Howells. New York: Oxford UP, 1997.

Arac, Jonathan. Huckleberry Finn as Idol and Target: The Functions of Criticism in Our

Time. Madison: University of Wisconsin Press, 1997.

Baker, Peter, and Michael A. Fletcher. "Rove to Leave White House Post," Washington Post. 14 August 2007.

Baym, Nina. "Melodramas of Beset Manhood: How Theories of American Fiction Exclude Women Authors," American Quarterly, 33 (1981): 123-139.

Bhabha, Homi K. "DissemiNation: Time, Narrative, and the Margins of the Modern Nation.” Nation and Narration. Ed. Bhabha. London: Routledge, 1990. Pp. 291-322.

Blight, David W. Race and Reunion: The Civil War in American Memory. Cambridge: Harvard University Press, 2003.

Bourdieu, Pierre. The Field of Cultural Production: Essays on Art and Literature. Ed.

Randal Johnson. Cambridge: Polity, 1993.

Brennan, Timothy. "The National Longing for Form." Nation and Narration. Ed. Homi 
K. Bhabha. London: Routledge, 1990. Pp. 44-70.

Brown, Herbert B. “The Great American Novel," American Literature, 7 (1935): 1-14.

Buell, Lawrence. "Hawthorne and the Problem of 'American Fiction': the Example of

The Scarlet Letter." Hawthorne and the Real: Bicentennial Essays. Ed. Millicent Bell.

Columbus: Ohio State University Press, 2005.

. “Observer-Hero Narrative,” Texas Studies in Literature and Language,

21 (1979): 93-111.

. "The Rise and 'Fall' of the Great American Novel," Proceedings of

the American Antiquarian Society, 104 (October 1994): 261-283.

Campbell, Charles A., Jr. “"The Great American Novel': A Study in Literary

Nationalism.” Ph. D. Diss., University of Minnesota, 1951.

Carlyle, Thomas. A History of the French Revolution: A History. New York: Modern

Library, 1934.

Casanova, Pascale. The World Republic of Letters. Trans. M. B. DeVevoise. Cambridge, MA: Harvard University Press, 2004.

DeForest, J. W. “The Great American Novel.” The Nation, 6 (9 January 1868): 27-29.

Derrida, Jacques. Specters of Marx: The State of the Debt, The Work of Mourning, and the New International. Trans. Peggy Kamuf. New York: Routledge, 1994.

Dreiser, Theodore. "The Great American Novel.” American Spectator Yearbook. New York: Frederick A. Stokes, 1934. Pp. 16-25.

Evans, Brad. Before Cultures: The Ethnographic Imagination in American Literature, 1865-1920. Chicago: University of Chicago Press, 2005.

Fluck, Winfried. Inzenierte Wirklichkeit: Der Amerikanische Realismus 1865-1900. 
Munich: Wilhelm Fink, 1992.

Foner, Eric. The Story of American Freedom. New York: Norton, 1998.

Giles, Paul. "The Deterritorialization of American Literature.” In Shades of the Planet:

American Literature as World Literature, ed. Wai Chee Dimock and Lawrence Buell. Princeton: Princeton University Press, 2007. Pp. 39-61.

Glissant, Edouard. Caribbean Discourse: Selected Essays. Trans. J. Michael Sash.

Charlottesville, VA: University Press of Virginia, 1989).

Hunt, Lynn. Inventing Human Rights. New York: Norton, 2007.

James, C. L. R. American Civilization. Ed. Anna Grimshaw and Keith Hart. Cambridge, MA: Blackwell, 1993.

James. C. L. R. Mariners, Renegades \& Castaways: The Story of Herman Melville and the World We Live In: The Complete Text. Ed. Donald E. Pease. Hanover: University Press of New England, 2001.

Kingston, Maxine Hong. “Cultural Mis-readings by American Reviewers,” Asian and Western Writers in Dialogue: New Cultural Identities, ed. Guy Amirthanayagam (London: Macmillan, 1982), 57-58.

Knox, George. "In Search of the Great American Novel," Western Review, 5 (Summer 1968): 64-77.

“The Great American Novel: Final Chapter," American Quarterly, 21

(Winter 1969): 667-682.

Labbe, François. Anacharsis Cloots: le Prussien Francophile. Paris: L'Harmattan, 1999. Mackethan, Lucinda H. "Huck Finn and the Slave Narratives: Lighting Out as Design," Southern Review, 20 (Spring 1984): 247-264Mailer, Norman. Quoted in The Odyssey of John 
Dos Passos, prod. Stephen Talbot . Annandale, VA: Educational Film Center, 1994.

Martin, Jay. Harvests of Change: American Literature, 1865-1915. Englewood Cliffs, NJ: Prentice-Hall, 1967.

Matthiessen, F. O. American Renaissance: Art and Expression in the Age of Emerson and Whitman. London: Oxford University Press, 1941.

McGurl, Mark. The Novel Art: Elevations of American Fiction After Henry James. Princeton: Princeton University Press, 2001.

Melville, Herman. Billy Budd, Sailor. Norton Anthology of American Literature, 18201865 (1923). $7^{\text {th }}$ ed. Ed. Nina Baym, et al. New York: Norton, 2007. Pp. 2468-2523. . The Confidence-Man (1857). Ed. Harrison Hayford et al. Evanston:

Northwestern University Press, 1984. . Moby-Dick or The Whale (1852). Ed. Harrison Hayford et al.

Evanston: Northwestern University Press, 1988.

Mensh, Elaine, and Harry Mensh. Black, White, and Huckleberry Finn: Re-Imagining the American Dream. Tuscaloosa: University of Alabama Press, 2000.

Morrison, Toni. “Unspeakable Things Unspoken: The Afro-American Presence in American Literature," Michigan Quarterly Review, 28 (Winter 1989): 1-34.

Norris, Frank. "The Great American Novelist." The Literary Criticism of Frank Norris. Ed. Donald Pizer. Austin: University of Texas Press, 1964. Pp. 122-124.

Paine, Thomas. 1790 "Preface" to The Age of Reason, Part the Second. Collected Writings. Ed. Eric Foner. New York: Library of America, 1995.

Pease, Donald E. "The Extraterritoriality of the Literature for Our Planet," ESQ: A Journal of the American Renaissance, 50. I-iii (2004). 
. Visionary Compacts: American Renaissance Writings in Cultural

Context. Madison: University of Wisconsin Press, 1987.

Perosa, Sergio. American Theories of the Novel, 1793-1903. New York: New York University Press, 1983.

Preston, Michael J. "Rethinking Folklore, Rethinking Literature: Looking at Robinson Crusoe and Gulliver's Travels as Folktales, A Chapbook-Inspired Inquiry." The Other Print Tradition: Essays on Chapbooks, Broadsides, and Related Ephemera. Ed. Cathy Lynn Preston and Michael J. Preston. New York: Garland, 1995. Pp. 19-73.

Renan, Ernest. "What is a Nation?” (1882). Rpt. Nation and Narration. Ed. Homi K. Bhabha. London: Routledge, 1990. Pp. 8-22.

Rogin, Michael. Subversive Genealogies: The Politics and Art of Herman Melville. New York: Knopf, 1983.

Rushdy, Ashraf H. A. Neo-slave Narratives: Studies in the Social Logic of a Literary Form. New York: Oxford University Press, 1999.

Schama, Simon. Citizens: A Chronicle of the French Revolution. New York: Knopf, 1989.

Schorer, Mark. Sinclair Lewis: An American Life. New York: McGraw-Hill, 1961.

Scott, A. O. "In Search of the Best," New York Times Book Review, 21 May 2006, 16-19.

Silber, Nina. The Romance of Reunion: Northerners and the South, 1865-1900. Chapel Hill: University of North Carolina Press, 1993.

Simpson, David. The Politics of American English. New York: Oxford University Press, 1986.

Smiley, Jane. “Say It Ain’t So, Huck: Second Thoughts on Mark Twain’s 
'Masterpiece,”' Harper's, 292 (January 1996): 61-67.

Smith, James McCune. "Horoscope," Frederick Douglass' Paper, rpt. The Works of James McCune Smith: Black Intellectual and Abolitionist. Ed. John Stauffer. New York: Oxford University Press, 2006.

Sommer, Doris. Foundational Fictions: The National Romances of Latin America. Berkeley: University of California Press, 1991.

Spanos, William. The Errant Art of Moby-Dick: The Canon, The Cold War, and the Struggle for American Studies. Durham: Duke University Press, 1995.

Thompson, G. Richard, and Eric Carl Link. Neutral Ground: New Traditionalism and the American Romance Controversy. Baton Rouge: Louisiana State University Press, 1999.

Thompson, Lawrance. Melville's Quarrel with God. Princeton: Princeton University Press, 1952.

Wharton, Edith. "The Great American Novel," Yale Review, 16, n.s. (1927): 646-656.

Williams, Alan. "Whatever Happened to the Great American Novel? (Part Deux)," Simon Magazine, 10 May 2007.

Williams, Raymond. The Country and the City. New York: Oxford University Press, 1973.

Winship, Michael. “'The Greatest Book of Its Kind': A Publishing History of 'Uncle Tom's Cabin," Proceedings of the American Antiquarian Society, 109.ii (1999): 309-332.

Wolfe, Tom. "Why They Aren't Writing the Great American Novel Anymore: A Treatise on the Varieties of Realistic Experience," Esquire, 78 (December 1972): 152-158, 272. 
Endnotes

1 In a letter of 1880 to William Dean Howells (Anesko 156-157). The context, a bemused reflection provoked by early notices of George Washington Cable's new novel The Grandissimes, is predictably ambiguous: it's impossible to say whether James is spoofing the whole idea or only the cliché-language of publishers' hypes.

2 See also for example Knox 1969, Brown, and Perosa. Martin is the mid-century critic to take the GAN idea most seriously.

3 Further disclosure: Asked about this statement in the late 1990s, Kingston opined to me that one today would wish rather to thin in terms of the "world" novel. But perhaps the disparate pronouncements are unsurprising given how Kingston's writing straddles "immigrant" and "diasporic."

4 Baym, personal correspondence.

5 Harriet Beecher Stowe, Uncle Tom's Cabin: The Great American Novel, to be completed in six weekly numbers, price one penny each Saturday, August 7, 1852 (London: Vickers, 1852). The prefatory "A Few Words to the British Reader" characterizes UTC as "the most interesting and startling work of the age. . . The work has produced, and is producing, such a sensation as no book ever produced before in America or in Europe." This rhetoric comports with the promotional puffery on both sides of Atlantic (see Winship).

6 For the fullest (but still quite incomplete) assemblage of documents, see Campbell. Buell 1994 covers some of the ground traversed here, but my thinking has changed considerably since then.

7 This for example this from a blogger who favors Last of the Mohicans (based perhaps on the film rather than the novel itself): "Found Moby Dick quite hard to get into, but after reading some of the above comments have decided to give it another go") (htto://thorntree.lonelyplanet.com/messagepost.cfm?postaction=reply\&catid=46\&threadid=1). As examples of late Victorian and turn-of-the-twenty-first century participatory discussion, compare the month-long controversy in the pages of the San Francisco Examiner by F. Bailey Millard's article "The Great American Novel" (27 December 1896) with the 2006 PBS special/online symposium on "The Great American Novel” (www.radioopensource.org/the-greatamerican-novel/) in the way of the New York Times poll (Scott).

8 The hypothesis that American fictional difference from British lay most distinctively in the former's preoccupation with "romance" as against "novelistic" modes most influentially derives 
from the mid-20th century critics Lionel Trilling and Richard Chase. For the most influential critique of its limitations, see Baym; for the most extended later attempted rehabilitation of the hypothesis, see Thompson and Link. For the most sophisticated adjudication, see McGurl.

9 A symptomatic instance is the Wikipedia entry for "Great American Novel" (1 June 2007): http://en.wikipedia.org/wiki/Great_American_Novel. To let one other example stand for all, see also Christopher Schmitz's list of twenty "Contenders for Great American Novel" posted for at least since 2005 by amazon.com. Huck Finn, Moby-Dick, and Scarlet Letter are ranked 1, 2, and 3, with Uncle Tom's Cabin in seventh place. (The top-ranked post-1950 novel is Kerouac's On the Road, in $11^{\text {th }}$ place.) (Http://www.amazon.com/Contenders-for-Great-AmericanNovel/1m/33H3DJF07GCDY)

10 See especially McGurl's calibrated account of the institutionalization of fictional modernism's aesthetic of difficulty in U. S. narrative practice as a discountenancing of Howellsian "militant probabalism" (46) not-at least during modernism's heyday-so much as a pursuit of anti-mimesis per se but as a valorization of smart vs. stupid.

11 The most influential statement has probably been Pease 1987, 235-275, as attested by, e.g., Spanos.

12 Http://www.cartoonstock.com ("Moby Dick cartoon 3). A noteworthy exception is a 1982 Gary Larson rear-view shot of a frustrated Ishmaelish scribbler straining for the right first sentence after five discards: "Call me Bill," etc. (Larson, The Complete Far Side [Kansas City: Andrews McMeel, 2003], 1: 190). Larson's several other cartoons that allude to Moby-Dick follow the norm $(1: 26,200,383)$.

13. "Ahab and the China Whale," quoting prominent Sinophile journalist Edgar Snow, The Nation, 17 May 1965; Anthony Lewis, "By Hate Possessed: Reagan's Nicaragua Obsession," New York Times, 24 March 1986; Arthur Schlesinger, Jr., "So Much for the Imperial Presidency," New York Times, 3 August 1998; Morrie Ryskind, "What Really Defeated Nixon," Los Angeles Times, 14 November 1962; John Leonard, "Mr. Nixon as the Last Liberal" (reviewing Gary Wills' Nixon Agonistes), New York Times, 15 October 1970; Lee Gomes, "The Microsoft Ruling: Rivals Rejoice but Await a Remedy Just as Tough," 8 November 1988; Wall Street Journal "Captain Ahab Prosecutors," Wall Street Journal editorial, 29 December 1988; John Gray, "Grits Unable to Satisfy Critics Despite Exit from Whale Group," (Toronto) Globe and Mail, 30 June 1981 Gillian Bennett, “'Camera, Lights, Action!': The British General Election 1992 as Narrative Event," Folklore, 107 (1996): 95; Ray Hanania, Mary Gillespie, Alf Siewers, "Name His Party!” Chicago Sun-Times, 30 May 1986; James Reston, "The Asterisk That Shook the Baseball World," New York Times, 1 October 1961

14 Morrison's own principal source in Melville studies was Rogin's interpretative biography. 
15 For research assistance, my sincere thanks to William Pannapacker, Christopher Le Coney, and Katie Gray. Portions of this essay were first tried out in lecture form at Oberlin College in 2005, at the 2007 Dartmouth Institute, and the 2007 IAUPE triennial convention in Lund. I am grateful for generous, valuable feedback received on all three occasions. 